Article

\title{
Ice Core Chronologies from the Antarctic Peninsula: The Palmer, Jurassic, and Rendezvous Age-Scales
}

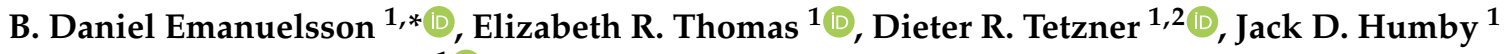 \\ and Diana O. Vladimirova ${ }^{1}$ (I)
}

1 Ice Dynamics and Paleoclimate Group, British Antarctic Survey, Natural Environment Research Council, High Cross, Madingley Road, Cambridge CB3 0ET, UK; lith@bas.ac.uk (E.R.T.); dietet95@bas.ac.uk (D.R.T.); jacby@bas.ac.uk (J.D.H.); diaadi@bas.ac.uk (D.O.V.)

2 Department of Earth Sciences, University of Cambridge, Downing Street, Cambridge CB2 3EQ, UK

* Correspondence: danem@bas.ac.uk

check for updates

Citation: Emanuelsson, B.D.;

Thomas, E.R.; Tetzner, D.R.; Humby, J.D.; Vladimirova, D.O. Ice Core Chronologies from the Antarctic Peninsula: The Palmer, Jurassic, and Rendezvous Age-Scales. Geosciences 2022, 12, 87. https://doi.org/ $10.3390 /$ geosciences 12020087 Academic Editors: Mirko Severi and Jesus Martinez-Frias

Received: 16 October 2021 Accepted: 30 January 2022 Published: 16 February 2022

Publisher's Note: MDPI stays neutral with regard to jurisdictional claims in published maps and institutional affiliations.

Copyright: (C) 2022 by the authors. Licensee MDPI, Basel, Switzerland. This article is an open access article distributed under the terms and conditions of the Creative Commons Attribution (CC BY) license (https:// creativecommons.org/licenses/by/ $4.0 /)$.

\begin{abstract}
In this study, we present the age scales for three Antarctic Peninsula (AP) ice cores: Palmer, Rendezvous, and Jurassic. The three cores are all intermediate-depth cores, in the 133-141 m depth range. Non-sea-salt sulfate $\left(\left[\mathrm{nssSO}_{4}{ }^{2-}\right]\right)$ and hydrogen peroxide $\left(\mathrm{H}_{2} \mathrm{O}_{2}\right)$ display marked seasonal variability suitable for annual-layer counting. The Palmer ice core covers 390 years, 1621-2011 C.E., and is one of the oldest AP cores. Rendezvous and Jurassic are lower elevation high-snow accumulation sites and therefore cover shorter intervals, 1843-2011 C.E. and 1874-2011 C.E., respectively. The age scales show good agreement with known volcanic age horizons. The three chronologies' start and end dates of volcanic events are compared to the volcanic events in the published WAIS Divide core. The age difference for the Palmer age scale is \pm 6 months, Rendezvous \pm 9 months, and Jurassic \pm 7 months. Our results demonstrate the advantage of dating several cores from the same region at the same time. Additional confidence can be gained in the age scales by evaluating and finding synchronicity of $\left[\mathrm{nsSO}_{4}{ }^{2-}\right]$ peaks amongst the sites.
\end{abstract}

Keywords: Antarctic Peninsula chronology; ice cores; volcanism; age-scales; annual-layer counting; water stable isotopes

\section{Introduction}

Ice core records have vastly improved our understanding of the earth's climate and enabled us to investigate past climates beyond the short observational era. Ice cores from low snow accumulation sites in the central Antarctic plateau have been used to reconstruct climate change over the past eight glacial cycles [1], while ice cores from high accumulation coastal sites can be used for high-resolution reconstructions [2,3]. Ice core proxies can be used to reconstruct past climate and extend limited spatially sparse observational records from Antarctica that only became available over the last half-century. However, the suitability of an ice core to reconstruct past climate or environmental changes is dependent on the accuracy of its age scale. This is especially important when identifying the phasing (lead or lags) of climatic events and when investigating the drivers of variability.

Choosing the appropriate dating approach is dependent on the conditions at the ice core site. For high accumulation sites, where it is possible to acquire high-resolution chemical records, annual-layer counting is the preferred method [4]. Annual-layer counting takes advantage of the seasonal deposition of chemical species, such as sea salts, continental ions, and biogenic aerosols, to an ice sheet. The stable water isotopes also provide a valuable seasonal marker in high latitude ice cores. The non-sea-salt part of the sulfate concentration $\left(\left[\mathrm{nssSO}_{4}{ }^{2-}\right]\right)$ can be estimated by removing the sea salt fraction [5],

$$
\left[\mathrm{nssO}_{4}^{2-}\right]=\left[\mathrm{SO}_{4}^{2-}\right]-0.251\left[\mathrm{Na}^{+}\right]
$$


where 0.251 is the $\left[\mathrm{SO}_{4}{ }^{2-} / \mathrm{Na}^{+}\right]$ratio in seawater. The source of $\left[\mathrm{nssSO}_{4}{ }^{2-}\right]$ is primarily from dimethyl sulfide (DMS) produced by phytoplankton blooms following the break-up of sea ice in austral spring (typically with onset in December) [6,7]. The chemical methane sulfonic acid (MSA) that is commonly measured in ice cores is an oxidation product from DMS [7]. Other [nssSO ${ }_{4}{ }^{2-}$ ] sources arrive in Antarctica via the troposphere and lower stratosphere; these sources are of volcanic, extrapolar biogenic, and anthropogenic origin. This input will also peak in early austral summer, because of the timing of the break-up of the polar vortex [6] (and references therein). However, at coastal sites, the biogenic-source $\left[\mathrm{nsSOO}_{4}{ }^{2-}\right.$ ] signal can drown the volcanic signal [6].

Another promising seasonal marker is hydrogen peroxide $\left(\mathrm{H}_{2} \mathrm{O}_{2}\right)$, a photochemical species that peaks during the summer solstice and with a minimum during the polar night. The clear seasonality of $\mathrm{H}_{2} \mathrm{O}_{2}$ has been used as a dating tool for several Antarctic ice cores [8-10]. The preservation of $\mathrm{H}_{2} \mathrm{O}_{2}$ in ice cores is dependent on the burial rate [9], and thus, high snow accumulation $\left(>0.22 \mathrm{~m} \mathrm{year}^{-1}\right)$ sites are most suitable for preserving atmospheric changes in $\mathrm{H}_{2} \mathrm{O}_{2}$. At low accumulation sites, the seasonal signal may be lost within the first few meters [11], while at warmer sites the signal is sensitive to melt [12].

Annual-layer counting has been used to date Antarctic ice cores back several thousand years [13]; however, an accumulative error can arise with depth. Thus, the presence of known reference horizons can be used to constrain age scales and determine the estimated dating uncertainties. The annual-layer counting can be supported by these independent reference horizons. These include known volcanic eruptions or unique and well-dated atmospheric signatures such as tritium peaks from nuclear bomb tests. The most widely used dating horizon is volcanic eruptions, detectable in ice cores as elevated levels of $\mathrm{SO}_{4}{ }^{2-}$, high conductivity, and/or in some cases the presence of tephra shards. For the former, a volcanic event is classified as significant if $\left[\mathrm{nsSO}_{4}{ }^{2-}\right]$ emerges above the biogenic background level by exceeding a threshold [e.g., background plus 2 standard deviations $(2 \sigma)$ ] [14-16]. Volcanic sulfate can have a delay of one to two years from the eruption until it shows a significant concentration in the firn or ice [17]. For example, Cole-Dai et al. [17] showed that most of the sulfate from Pinatubo (eruption date 1991) was deposited between 1992 and 1994.

In this study, we present the age scales for three ice cores from the Antarctic Peninsula (AP). These ice cores will ultimately be used to investigate regional climate and surface mass balance variability, at annual to decadal timescales. However, first, we must establish accurate age-scales. The aim of this study is to (1) provide a chronology for each site, based on annual layer counting, (2) explore the seasonal cycle of chemical and isotopic records used for annual layer counting, (3) examine the volcanic horizons present in each core and how they compare between sites.

\section{Data and Methods}

\subsection{Drill Sites}

The Palmer, Rendezvous, and Jurassic cores were all drilled in November-December 2012 using the British Antarctic Survey (BAS) electromechanical dry drill (without drill fluid) (Table 1). Palmer is a high-elevation AP drill site, while the Rendezvous and Jurassic cores were retrieved at lower elevations (Figure 1 and Table 1) [18]. The Palmer and Rendezvous sites are located on local ridges and the Jurassic core was retrieved slightly northwest of a local summit (Figure 1b). All locations are situated at sufficiently high elevation to not be affected by ice sheet flank flow. The sites are located at adequately high elevations so that the chemical records are not compromised by melt (see the $-10 \mathrm{~m}$ temperatures, Table 1). The precipitation pathways, meteorological setting, estimated precipitation rates, and geographical background of these sites are summarized in Thomas and Bracegirdle [18]. Using ERA-Interim reanalysis data [19] (1979-2011) they estimated the annual average precipitation minus evaporation to be 49,99 , and $95 \mathrm{~cm}$ w.e. (water equivalent) for Palmer, Rendezvous, and Jurassic, respectively [18]. 
Table 1. Drill site and core characteristics.

\begin{tabular}{cccccccc}
\hline & Latitude & Longitude & $\begin{array}{c}\text { Elevation } \\
\text { (m a.s.1.) }\end{array}$ & Drill Date & $\begin{array}{c}\text { Depth (m } \\
\text { below the } \\
\text { Snow Surface) }\end{array}$ & $\begin{array}{c}\text { Age Range } \\
\text { (C.E.) }\end{array}$ & $\begin{array}{c}-\mathbf{1 0} \mathbf{m} \\
\text { Temperature } \\
\left({ }^{\circ} \mathbf{C}\right)\end{array}$ \\
\hline Palmer & $73.86^{\circ} \mathrm{S}$ & $65.46^{\circ} \mathrm{W}$ & 1897 & 24-29 December 2012 & $0-133$ & $1621-2011$ & -22.4 \\
Rendezvous & $74.45^{\circ} \mathrm{S}$ & $78.16^{\circ} \mathrm{W}$ & 1006 & 9-16 December 2012 & $0-141$ & $1843-2011$ & -23.8 \\
Jurassic & $74.33^{\circ} \mathrm{S}$ & $73.06^{\circ} \mathrm{W}$ & 1139 & 19-27 November 2012 & $0-140$ & $1874-2011$ & -16.7 \\
\hline
\end{tabular}
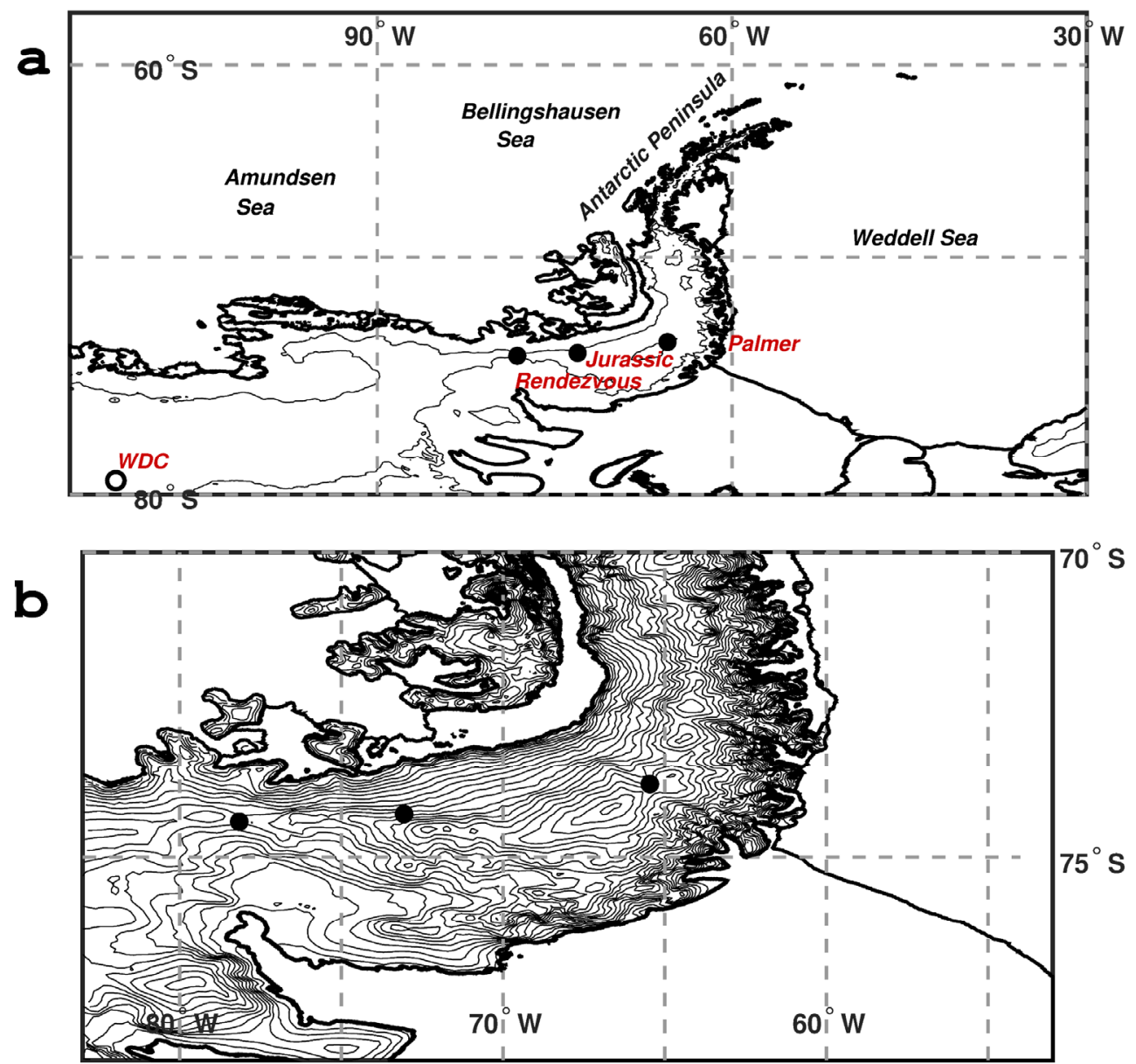

Figure 1. Antarctic location maps. Ice-core sites for which chronologies are established in this study are indicated by black dots. (a) The location of a WDC core (WDC06A) is indicated by a black circle. Contours (thin black lines) with $1000 \mathrm{~m}$ spacing indicate elevation above sea level [20,21]. (b) shows a blow-up map of the Antarctic Peninsula ice core locations. Contours (thin black lines) with $100 \mathrm{~m}$ spacing indicate elevation above sea level $[20,21]$. WDC-WAIS Divide ice core.

The Palmer, Rendezvous, and Jurassic ice cores were drilled as part of a suite of cores [18], with the initial goal of providing an opportunity to compare the seasonal deposition of chemical species across a high snow accumulation region.The Palmer core is one of the paleo archives that will be utilized by the Anthropocene Working Group with the overarching goal to pinpoint the start of the Anthropocene. Thus, there is a need to establish accurate age-scales as a foundation for future analyses.

\subsection{Datasets}

\subsubsection{Chemistry Data}

A suite of chemical species was measured using Continuous Flow Analysis (CFA) in the ice core labs at BAS (Cambridge, UK). The bespoke CFA system comprises Fast 
Ion Chromatography (FIC), Inductively Coupled Plasma Mass Spectrometry (ICP-MS), fluorescence, and laser spectroscopy instrumentation [22]. All instruments are engineered for operation in continuous mode, where ice core sections are melted and analysed from a continuous sample stream [23]. In this study, we use hydrogen peroxide $\left(\mathrm{H}_{2} \mathrm{O}_{2}\right)$ for the three sites, together with continuous water isotopes for the Palmer ice core. We also use discrete samples. Discrete samples were cut at $5 \mathrm{~cm}$ resolution and melted in precleaned polythene containers. The melted samples were analysed using ion chromatography in a class-100 clean laboratory. Anions were measured on a Dionex ICS-2500 ion chromatograph, in this study we use MSA and $\left[\mathrm{SO}_{4}{ }^{2-}\right]$ anions. Cations were measured using a Dionex ICS-2000 ion chromatograph, we use the $\left[\mathrm{Na}^{+}\right]$ions. Sodium data are missing for a section of the Rendezvous core (35.05-39 m) and Jurassic core (133.75-140 m), therefore, [ $\mathrm{nssSO}_{4}{ }^{2-}$ ] is not available for these sections.

\subsubsection{Water Stable Isotope Records}

We use the high-resolution water stable isotope records from the Palmer, Rendezvous, and Jurassic cores. The $\delta$-notation is the common way of representing the low abundance isotopes, as a deviation from a reference ratio:

$$
\left.\delta=1000\left[\mathrm{R} / \mathrm{R}_{\mathrm{V}-\mathrm{SMOW}}-1\right] \text { (given in per mil, \% }\right),
$$

where $R$ and $R_{V-S M O W}$ are the ratios between rare and abundant isotopes $R=n\left({ }^{18} \mathrm{O}\right) / n\left({ }^{16} \mathrm{O}\right)$, or $\mathrm{R}=\mathrm{n}(\mathrm{D}) / \mathrm{n}(\mathrm{H})$ in the sample and V-SMOW (Vienna-Standard Mean Ocean Water), respectively.

The Palmer water isotopes were measured using a Picarro analyzer (L2130-i) with an adjoined custom-made continuous-flow setup comparable to [24,25] and similar systems [26-28]. Gkinis et al. [24,25] first introduced laser spectroscopy measurement for ice core water isotope CFA measurements, showing its benefit in providing less labourintensive high-resolution, concurrent $\delta^{18} \mathrm{O}$ and $\delta \mathrm{D}$ measurements. The Rendezvous and Jurassic water isotopes were measured from discrete samples with a $5 \mathrm{~cm}$ resolution on a Los Gatos Research Inc. (LGR) Liquid Water Isotope Analyzer (LWIA-DLT 100).

Internal standards, calibrated to the V-SMOW2/Standard Light Antarctic Precipitation 2 (V-SMOW2/SLAP2) scale, were used to calibrate the isotope records. We use $\delta^{18} \mathrm{O}$ in the subsequent analysis.

\subsection{Methods}

\subsubsection{Annual-Layer Counting}

Figure 2 shows example sections from the Palmer core where $\left[\mathrm{nssSO}_{4}{ }^{2-}\right], \mathrm{H}_{2} \mathrm{O}_{2}, \delta^{18} \mathrm{O}$, and MSA records are plotted against depth. The annual-layer markers for dating of the cores were determined using $\left[\mathrm{nssSO}_{4}{ }^{2-}\right], \mathrm{H}_{2} \mathrm{O}_{2}, \delta^{18} \mathrm{O}$, and MSA summer peaks (indicated by vertical dashed black lines in Figure 2). Due to its clear seasonality, and its distinct summer peaks throughout the record, $\left[\mathrm{nssSO}_{4}{ }^{2-}\right]$ was chosen as the primary chemical for annual layer markers and their timing (assigned as the 1st of January) (Figures 2 and 3). The $\delta^{18} \mathrm{O}, \mathrm{H}_{2} \mathrm{O}_{2}$, and MSA records were evaluated simultaneously with the $\left[\mathrm{nssSO}_{4}{ }^{2-}\right.$ ] record. Figure $2 b$ shows that the seasonal signal for the $\left[\mathrm{nssSO}_{4}{ }^{2-}\right], \mathrm{H}_{2} \mathrm{O}_{2}, \delta^{18} \mathrm{O}$ species remains viable as age markers at deeper depths. 

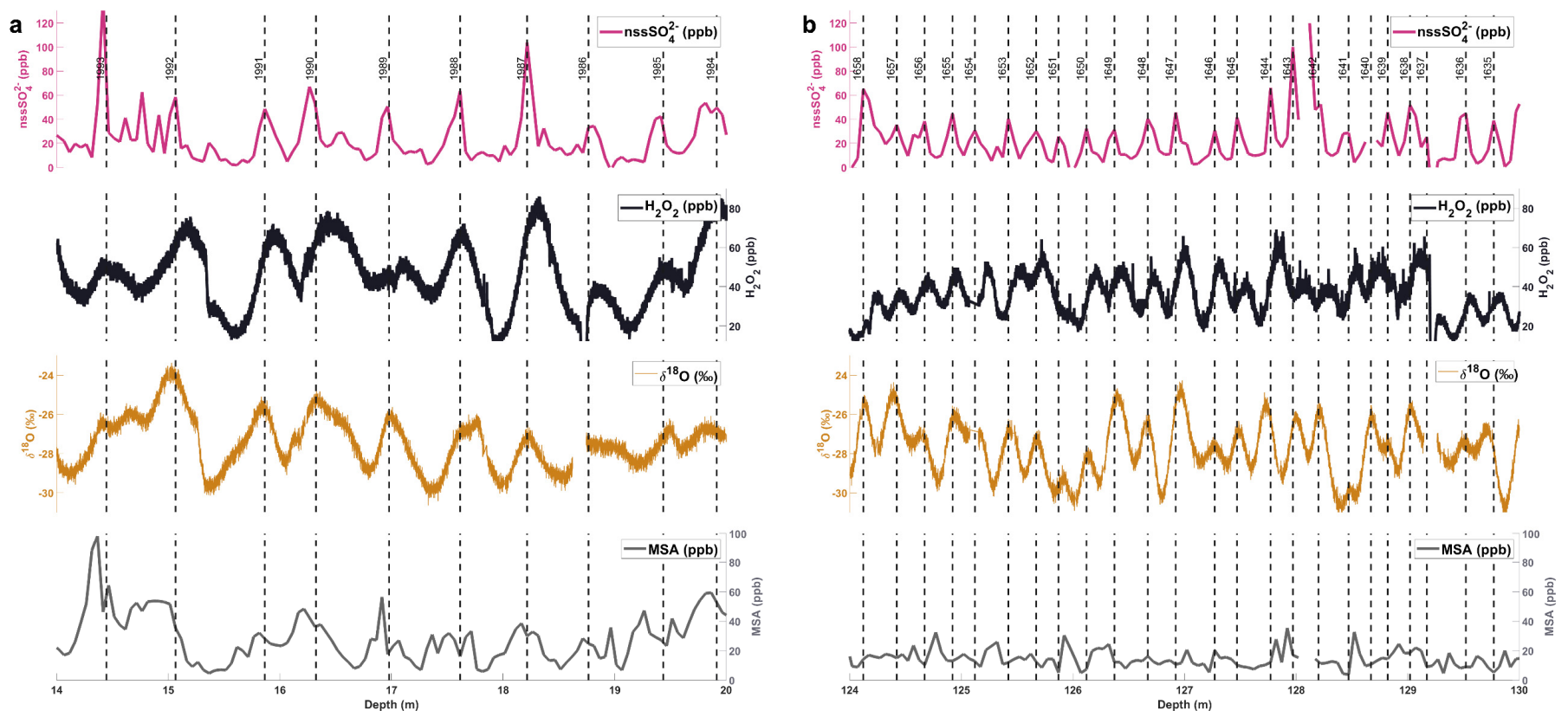

Figure 2. Example intervals of chemical signals in the Palmer ice core. Non-sea-salt sulfate [[nssSO $\left.{ }_{4}{ }^{2-}\right]$, magenta line (ppb)], hydrogen peroxide $\left[\mathrm{H}_{2} \mathrm{O}_{2}\right.$, black line], $\delta^{18} \mathrm{O}$ [yellow line, $\left.(\%)\right]$, and MSA [grey line, (ppb)] plotted against depth (measured from the snow surface) (a) 14-20 m, (b) 124-130 m. Annual-layer markers are indicated by dashed vertical lines.

The $\mathrm{H}_{2} \mathrm{O}_{2}$ signal is well preserved throughout the Rendezvous and Jurassic records. However, a period of lower snow accumulation at the Palmer site results in a period of poor $\mathrm{H}_{2} \mathrm{O}_{2}$ signal preservation $(\sim 30-55 \mathrm{~m}, 1962-1895)$. The $\mathrm{H}_{2} \mathrm{O}_{2}$ signal is maintained throughout the full length of the Rendezvous and Jurassic profiles, but for consistency, we have chosen to use $\left[\mathrm{nssSO}_{4}{ }^{2-}\right.$ ] as our primary indicator for layer counts for all sites.

Similarly, the seasonal MSA signal (summer peak) is well preserved in Rendezvous and Jurassic throughout the core. However, for Palmer, the MSA peak shifts to mid-winter for certain deeper sections (e.g., Figure 2b). This type of shift has also been reported for other Antarctic Peninsula cores [7,29]. The shift can be due to a change of source region [7]. It has also been suggested that the peak shift from summer to winter with depth is caused by the migration of MSA [7]. However, for Palmer, summer peaks still occur at deeper depths, but less frequently.

Sodium data are missing for the deepest part of the Jurassic core $(133.75-140 \mathrm{~m})$. Therefore, $\left[\mathrm{nsSSO}_{4}{ }^{2-}\right]$ cannot be calculated for this section. However, for this interval $\mathrm{H}_{2} \mathrm{O}_{2}$ displays clear seasonality and together with the other records, it is still possible to unambiguously date this section. The age scales for the three cores are provided as downloadable files from the NERC EDS UK Polar Data Centre [30] (However, the files will at publication date be embargoed and will be made accessible online in July 2022). 

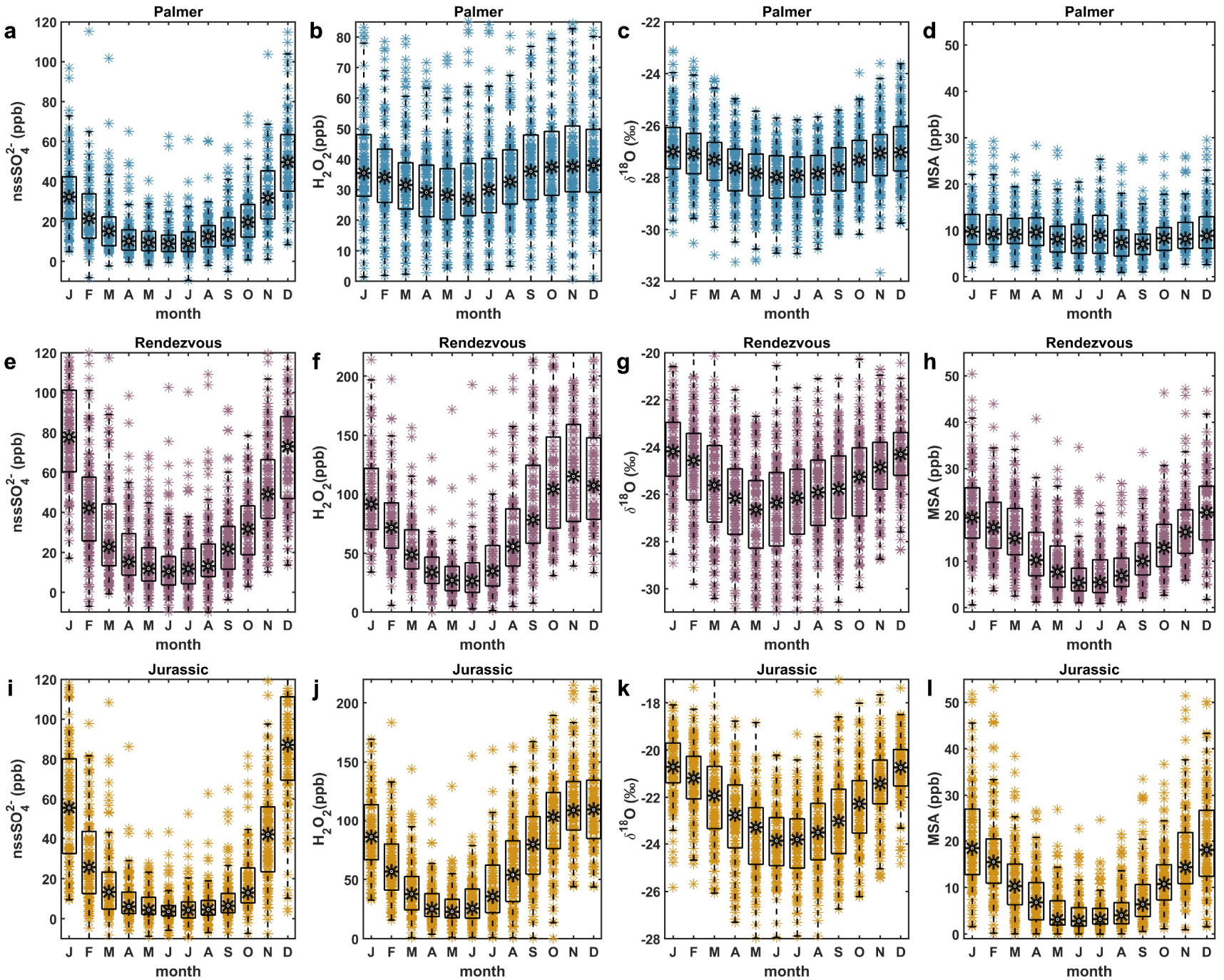

Figure 3. Seasonality of non-sea-salt sulfate [[nssSO $\left.{ }_{4}{ }^{2-}\right]$, (parts per billion, ppb)], hydrogen peroxide $\left[\mathrm{H}_{2} \mathrm{O}_{2},(\mathrm{ppb})\right], \delta^{18} \mathrm{O}(\%)$, and methane sulfonic acid [MSA (ppb)] for the Palmer [top row (a-d), blue asterisks; 1874-2011 (the maximum overlapping period between the cores)], Rendezvous [middle row (e-h), purple asterisks; 1874-2011] and Jurassic [bottom row (i-1), yellow asterisks; 1874-2011] ice core sites. The monthly averages of chemical concentrations and isotope ratios are plotted against month. In the box plots the black asterisks shows the median values for all monthly values for each month, the box indicates the 25th and 75th percentiles, and the whiskers extend to the most extreme data points that are not classified as outliers. The panels are zoomed in to show the regions of interest clearly and do not display all values. Note the difference in scale on the $y$-axis between the sites for $\mathrm{H}_{2} \mathrm{O}_{2}$ and $\delta^{18} \mathrm{O}$.

\subsubsection{Defining Volcanic Horizons}

We identified volcanic events in the cores by finding $\left[\mathrm{nsSO}_{4}{ }^{2-}\right.$ ] annual concentrations that were elevated above the background level. Annual averages of $\left[\mathrm{nsSO}_{4}{ }^{2-}\right]$ were calculated using winter-to-winter years (e.g., the year 1900 is the average of $\left[\mathrm{nsSO}_{4}{ }^{2-}\right.$ ] data for the 1899.5-1900.5 interval). This approach was chosen to avoid splitting the pronounced $\left[\mathrm{nsSOO}_{4}{ }^{2-}\right]$ summer peaks into different calendar years. The $\left[\mathrm{nssSO}_{4}{ }^{2-}\right]$ concentration records have non-gaussian distributions. The log-normal of the concentration was therefore calculated and the background [nssSO ${ }_{4}{ }^{2-}$ ] level was determined by first excluding the bottom 5th and top 95th percentile of the data. This excludes low values caused by high $\left[\mathrm{Na}^{+}\right]$concentrations and volcanic peaks. For the remaining data, the background was determined by smoothing the data with a running average of 31-years. A 31-year moving 
window is used as it provides a standard period for climatological variability [31]. The results are not dependent on this specific window size (e.g., a 21-year or 41-year window gives the same results). Subsequently, the standard deviation of the background was calculated and the mean plus the $1 \sigma$ and $2 \sigma$ were utilized to find events that stand out above the background.

We also conducted a similar analysis on the high-resolution $\left[\mathrm{nsSO}_{4}{ }^{2-}\right]$ concentration records. First, the 95th percentile of the data was removed, then the moving average and $\sigma$ were determined. A 201-point moving average was applied for Palmer (453 points for Rendezvous and 563 points for Jurassic), which equals approximately 31 years in the middle of each core. For the high-resolution concentration records, neighbouring points (up to two measurements away) to an exceedance of $3 \sigma$ ( $4 \sigma$ for Rendezvous and Jurassic) were investigated and if at least one neighbouring point exceeded $2 \sigma$, the $3 \sigma$ exceedance was classified as a volcanic event. The following restrictive approach was adopted to avoid the classification of potential outliers from contamination as volcanic events. Note that the main significance test in this study and its reported exceedances come from the more conservative analysis using the log-normal of the annual concentration records [15]. The high-resolution concentration records are shown for comparison and to obtain the sub-annual resolved start and end dates of the volcanic events.

\section{Results and Discussion}

\subsection{Age Scales}

\subsubsection{Seasonality}

A date is calculated for each sample/measurement depth by linear interpolation between the age markers. Subsequently, monthly means are calculated. This is done without claiming monthly resolution for specific monthly values, however, the median of all monthly values will give the seasonality of a typical year. The chemical concentrations and isotope ratios are plotted against month (Figure 3). The seasonality is assessed over the maximum overlapping period of the cores, 1874-2011. All ages in this study are in C.E. (A.D.).

The seasonality of the $\left[\mathrm{nsSO}_{4}{ }^{2-}\right], \mathrm{H}_{2} \mathrm{O}_{2}, \delta^{18} \mathrm{O}$, and MSA is presented in Figure 3 for the Palmer, Rendezvous, and Jurassic cores. All species show clear seasonality across all sites, except for MSA and $\mathrm{H}_{2} \mathrm{O}_{2}$ at Palmer, which does not show seasonality throughout the record (discussed further in Section 2.3.1). This confirms that the chosen sample resolution at these sites is sufficiently high to preserve seasonal signals. On average Palmer, Rendezvous and Jurassic have 6.6, 15.6, and $18.7\left[\mathrm{nssSO}_{4}{ }^{2-}\right]$ measurements per year, respectively. Other chemical impurity records were evaluated but were not suitable for layer counting as they did not show a clear seasonal cycle. Several impurity records concentrations (e.g., $\left[\mathrm{Cl}^{-}\right],\left[\mathrm{Mg}^{2+}\right],\left[\mathrm{Na}^{+}\right]$) appear to vary with the amount of storminess and sea ice, which show biannual or more cycles per year [18]. The peaks differ in timing depending on the weather. Therefore, we have not employed them in this study for dating.

At all sites, the $\mathrm{H}_{2} \mathrm{O}_{2}$ summer peak precedes the $\left[\mathrm{nsSO}_{4}{ }^{2-}\right.$ ] and $\delta^{18} \mathrm{O}$ peaks by about 1 month. This is consistent with $\mathrm{H}_{2} \mathrm{O}_{2}$ peaking at the summer equinox and [ $\mathrm{nssO}_{4}{ }^{2-}$ ] at the beginning of January.

\subsubsection{Volcanic Horizons}

The volcanic horizons identified in the Palmer, Rendezvous, and Jurassic $\left[\mathrm{nssO}_{4}{ }^{2-}\right]$ records are presented in Figure 4. Significant $(\geq 2 \sigma)$ bipolar (identified both in the Arctic and Antarctic ice cores) volcanic events are indicated by grey shading. The events identified in Figure 4 and Table 2 are not an exhaustive list; for this section we have chosen to focus only on peaks that have been extensively identified in other Antarctic cores, including in the high-resolution WAIS Divide core [32]. Bipolar events originate from large tropical volcanic eruptions, which connects to the polar regions via the stratosphere [32]. There is, therefore, no surprise that these events are present in AP records. 

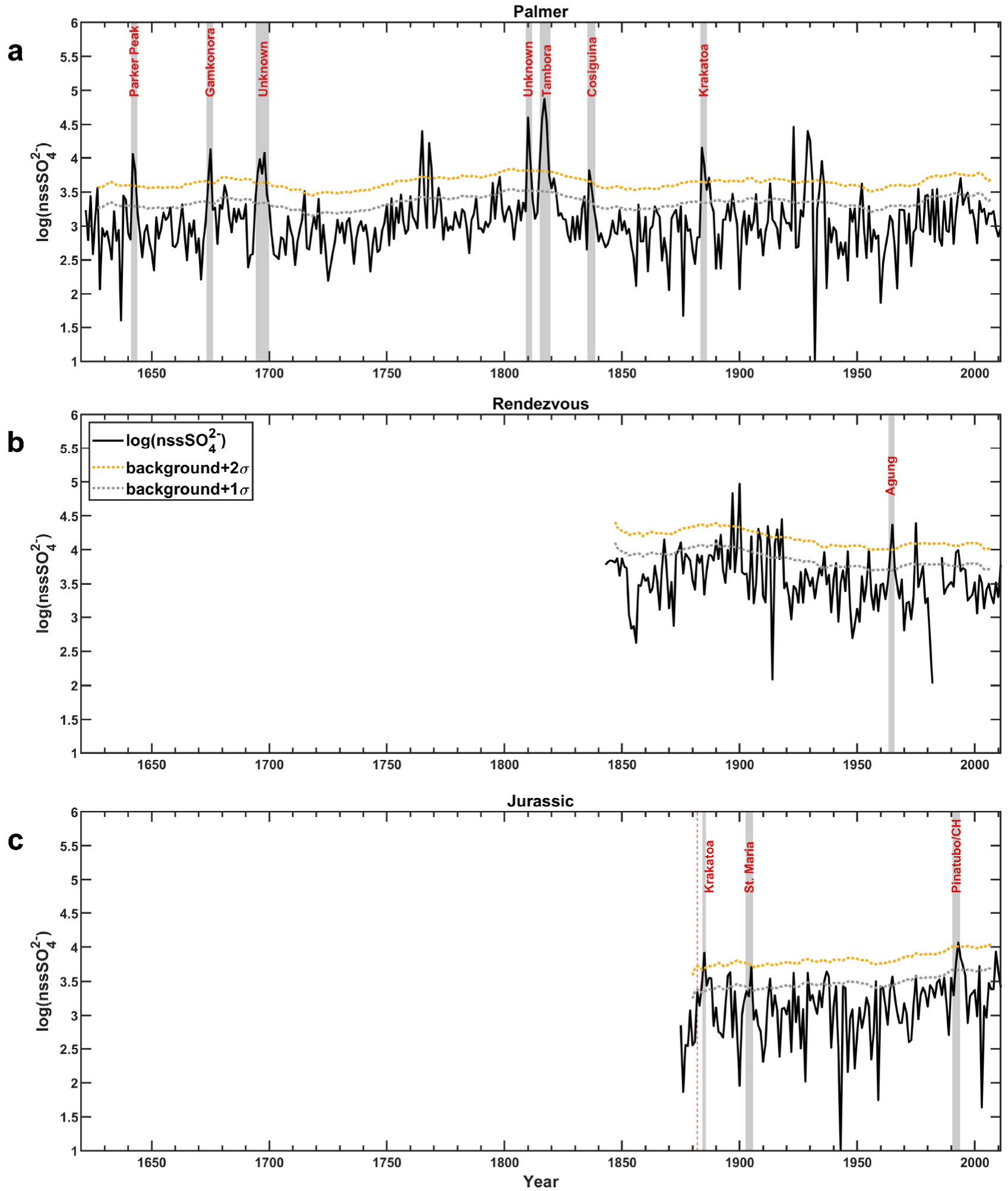

Figure 4. The log-normal of the annually averaged non-sea-salt sulfate records ([nssSO $\left.{ }_{4}^{2-}\right]$, black line) for (a) Palmer, (b) Rendezvous, and (c) Jurassic. Grey shading indicates volcanic events $\left[\log \left(\left[\mathrm{nssSO}_{4}{ }^{2-}\right]\right) \geq\right.$ background $\left.+2 \sigma\right]$. The indicated events are bipolar events that have been identified in the WAIS divide and NEEM cores [nssSO ${ }_{4}{ }^{2-}$ ] records [32]. The dashed red line in c indicates the period (1874-1882) for which the $\log \left(\left[\mathrm{SO}_{4}{ }^{2-}\right]-0.251^{*}\right.$ average $\left.\left(\left[\mathrm{Na}^{+}\right]\right)\right)$record is displayed for Jurassic. The Pinatubo and Cerro Hudson (CH) eruptions occurred almost simultaneously in 1991, and they are therefore not separable in ice core $\mathrm{SO}_{4}{ }^{2-}$ records [16]. 
Table 2. Start and end dates of volcanic bipolar events identified in the Palmer (a), Rendezvous (b), and Jurassic (c) cores. The volcanic horizons (start and end dates) are compared to the event dates reported in the independently dated high-resolution WAIS Divide core (WDC06A) [32]. Diff.-difference, CH—Cerro Hudson.

\begin{tabular}{|c|c|c|c|c|c|c|c|c|c|c|c|c|}
\hline \multirow{2}{*}{$\frac{\text { a }}{\text { Volcano }}$} & \multirow[b]{2}{*}{$\begin{array}{l}\text { Year of } \\
\text { Eruption }\end{array}$} & \multirow{2}{*}{$\begin{array}{c}\text { Palmer } \\
\text { Start Depth }\end{array}$} & \multicolumn{5}{|l|}{$\mathrm{nssSO}_{4}{ }^{2-}$} & \multicolumn{3}{|c|}{ WDC } & \multicolumn{2}{|c|}{ Diff. w. WDC } \\
\hline & & & End Depth & Start Date & End Date & $\log ($ Conc. $) 2 \sigma$ & Conc. $2 \sigma$ & $\begin{array}{l}\text { High-res. } \\
\text { Conc. } 2 \sigma\end{array}$ & Start Date & End Date & Start Date & End Date \\
\hline Pinatubo/CH & 1991 & 14.52 & 13.52 & 1991.9 & 1994.4 & & $x$ & $x$ & 1991.5 & 1993.5 & 0.4 & 0.9 \\
\hline Agung & 1963 & 29.72 & 29.07 & 1963.8 & 1965.1 & & & $x$ & 1963.6 & 1965.6 & 0.2 & 0.5 \\
\hline Krakatoa & 1883 & 59.22 & 58.67 & 1883.8 & 1885.7 & $x$ & $x$ & $x$ & 1884 & 1886.4 & 0.2 & 0.7 \\
\hline Cosiguina & 1835 & 75.91 & 74.99 & 1835.7 & 1838.2 & $x$ & $x$ & $x$ & 1834.7 & 1838.2 & 1 & 0 \\
\hline Tambora & 1815 & 81.87 & 80.84 & 1815.5 & 1819.1 & $\mathrm{x}$ & $\mathrm{x}$ & $\mathrm{x}$ & 1815.4 & 1818.4 & 0.1 & 0.7 \\
\hline $\begin{array}{l}\text { Unknown } \\
1809\end{array}$ & - & 83.67 & 83.03 & 1809.5 & 1811.3 & $x$ & $x$ & $x$ & 1809.4 & 1812.1 & 0.1 & 0.8 \\
\hline $\begin{array}{c}\text { Unknown } \\
1694\end{array}$ & - & 114.47 & 113.22 & 1694.7 & 1699.5 & $\mathrm{x}$ & $\mathrm{x}$ & $x$ & 1694.6 & 1697.4 & 0.1 & 2.1 \\
\hline Gamkonora & 1673 & 120.05 & 119.57 & 1673.7 & 1675.7 & $x$ & $x$ & $x$ & 1673.7 & 1676 & 0 & 0.3 \\
\hline \multirow[t]{2}{*}{ Parker Peak } & 1640 & 128.27 & 127.87 & 1641.7 & 1643.5 & $x$ & $\mathrm{x}$ & $\mathrm{x}$ & 1641.6 & 1643.7 & 0.1 & 0.2 \\
\hline & & & & & $\begin{array}{l}\text { total number of } \\
\text { exceedances: }\end{array}$ & 14 & 16 & $\sim 28$ & & & mean diff.: & 0.47 \\
\hline $\mathbf{b}$ & & Rendezvous & $\mathrm{nssSO}_{4}{ }^{2-}$ & & & & & & & & \multicolumn{2}{|c|}{ Diff. w. WDC } \\
\hline Volcano & & Start Depth & End Depth & Start Date & End Date & $\log ($ Conc. $) 2 \sigma$ & Conc. $2 \sigma$ & $\begin{array}{l}\text { High-res. } \\
\text { Conc. } 2 \sigma\end{array}$ & & & Start Date & End Date \\
\hline Pinatubo/CH & 1991 & 28.58 & 27.3 & 1991.8 & 1993.0 & & $x$ & $x$ & 1991.5 & 1993.5 & 0.3 & 0.5 \\
\hline Agung & 1963 & 56.35 & 54.7 & 1963.8 & 1965.5 & $x$ & $x$ & $x$ & 1963.6 & 1965.6 & 0.2 & 0.1 \\
\hline \multirow[t]{2}{*}{ St. Maria } & 1902 & 101.4 & 100.9 & 1904.8 & 1905.7 & & $\mathrm{x}$ & $x$ & 1902.9 & 1904.3 & 1.9 & 1.4 \\
\hline & & & & & $\begin{array}{l}\text { total number of } \\
\text { exceedances: }\end{array}$ & 7 & 10 & $\sim 21$ & & & mean diff.: & 0.73 \\
\hline c & & Jurassic & $\mathrm{nssSO}_{4}{ }^{2-}$ & & & & & & & & \multicolumn{2}{|c|}{ Diff. w. WDC } \\
\hline Volcano & & Start Depth & End Depth & Start Date & End Date & $\log ($ Conc. $) 2 \sigma$ & Conc. $2 \sigma$ & $\begin{array}{l}\text { High-res. } \\
\text { Conc. } 2 \sigma\end{array}$ & & & Start Date & End Date \\
\hline Pinatubo/CH & 1991 & 38.29 & 35.65 & 1990.9 & 1993.3 & $x$ & $x$ & $x$ & 1991.5 & 1993.5 & 0.6 & 0.2 \\
\hline St. Maria & 1902 & 119.2 & 117.88 & 1902.7 & 1905.3 & & $x$ & $\mathrm{x}$ & 1902.9 & 1904.3 & 0.2 & 1 \\
\hline \multirow[t]{2}{*}{ Krakatoa } & 1883 & 132.05 & 131.6 & 1884.6 & 1885.3 & $\mathrm{x}$ & $x$ & $x$ & 1884 & 1886.4 & 0.6 & 1.1 \\
\hline & & & & & $\begin{array}{l}\text { total number of } \\
\text { exceedances: }\end{array}$ & 2 & 4 & $\sim 21$ & & & mean diff.: & 0.62 \\
\hline
\end{tabular}


We compare the dates of the volcanic events (start and end date) with dated historical eruptions and observed volcanic events in the WAIS Divide ice core chronology (core WDC06A) [13,32], a high-accumulation site with a well-constrained age scale. We find eight volcanic horizons in the Palmer $\left[\mathrm{nsSO}_{4}{ }^{2-}\right]$ record that matches events identified in the WAIS Divide core [32] (Table 2a), proving the volcanic nature of these events. Since the events line up without any applied corrections (the events are not used as tie points) they provide confidence in our layer-count methodology. The average of the absolute age differences between the cores, which provides a measure of uncertainty error for the age scales, does not exceed \pm 6 months for Palmer (Table $2 a$ ). The analysis shows that the uncertainty error for the Palmer age scale is not cumulative, that is, it does not show a significant uncertainty increase over the recovered depth interval.

The Rendezvous and Jurassic records comparison with the WAIS Divide core include four significant ( $\geq 2 \sigma$ level) matching events: Rendezvous-Pinatubo/ $\mathrm{CH}$, Agung; Jurassic-Pinatubo/CH, and Krakatoa (Table 2b,c). The Rendezvous $\log \left(\left[\mathrm{nssSO}_{4}{ }^{2-}\right]\right)$ record does not exceed the $2 \sigma$ threshold for Pinatubo/ $\mathrm{CH}$, but the annual concentration record does exceed the $2 \sigma$ level and it is therefore included in Table 2. The St. Maria event was not classified as bipolar by Sigl et al. [32], but is included (Table 2b,c and Figure 4c) as Kohno and Fujii's [33] ice core analysis indicates that it was a bipolar event. The estimated age uncertainty for these cores is 9 and 7 months for Rendezvous and Jurassic, respectively (Table 2b,c).

All cores are similar in length, but the Rendezvous and Jurassic cores are retrieved from higher accumulation sites compared to Palmer [18] and therefore cover shorter periods (Table 2). Consequently, Rendezvous and Jurassic do not include the deeper (older) major volcanic horizons that the Palmer core contains.

The lower elevation of the Rendezvous and Jurassic sites is also reflected in their higher $\left[\mathrm{nsSO}_{4}{ }^{2-}\right.$ ] background level compared to the record from the high-altitude Palmer site. The Rendezvous and Jurassic $\left[\mathrm{nssSO}_{4}{ }^{2-}\right]$ signals are, therefore, more likely to become overwhelmed by $\left[\mathrm{nsSO}_{4}{ }^{2-}\right]$ biogenic input.

The number of detected potential volcanic events depends marginally on the chosen method; applying the log-normal of annually-averaged $\left[\mathrm{nsSO}_{4}{ }^{2-}\right.$ ] concentration is a more conservative approach compared to annual concentration values and the high-resolution analysis (Table 2) [15]. Log-normal of [nssSO ${ }_{4}^{2-}$ ] flux is the most conservative approach [15]. However, to keep the analysis simple and not introduce any potential errors associated with the accumulation record (or its corrections) we stick to log-normal of concentrations.

Figure 5 shows the log-normal of the annually averaged $\left[\mathrm{nsSO}_{4}{ }^{2-}\right.$ ] concentration records for Palmer, Rendezvous, Jurassic, and WDC. This figure highlights common peaks among the records. In addition to the bipolar events identified in Figure 4, we identify additional volcanic horizons that previously have been reported in Antarctic ice cores and common features between the records that potentially can have a volcanic origin. This includes one unknown event identified in this study. The events that match known bipolar events are unequivocal volcanic events. Whereas the additional event (Unknown*) are less certain and can also have a marine biogenic origin.

Palmer and WDC display in sync significant exceedances for the deeper part of the record (Unknow 1809, Tambora, Cosiguina). A close match also occurs for the deeper overlapping part of the records (Unknown 1694, Gamkonora, Parker Peak; Table 2a).

The WDC $(>2 \sigma)$ and Palmer $(>1 \sigma)$ records show significant exceedances in 1864, which corresponds to the Makian (Indonesia) eruption [32]. The Jurassic $(>2 \sigma)$, Rendezvous $(>1 \sigma)$ and WDC $(>1 \sigma)$ records display significant exceedances in 1904-1905, which corresponds to St. Maria (Guatemala) eruption [32]. The Rendezvous $(>2 \sigma)$, Palmer $(>1 \sigma)$, and Jurassic $(>1 \sigma)$ records show significant exceedances in 1912. This peak has also been reported in an ice core from Enderby Land, East Antarctica, and was attributed to a Deception Island eruption [33]. The Palmer core shows significant [nssSO ${ }_{4}{ }^{2-}$ ] exceedances around 1929 associated with an unknown potential volcanic event (marked as Unknown* in Figure 5). This event was also present in the Enderby Land core [33]. 


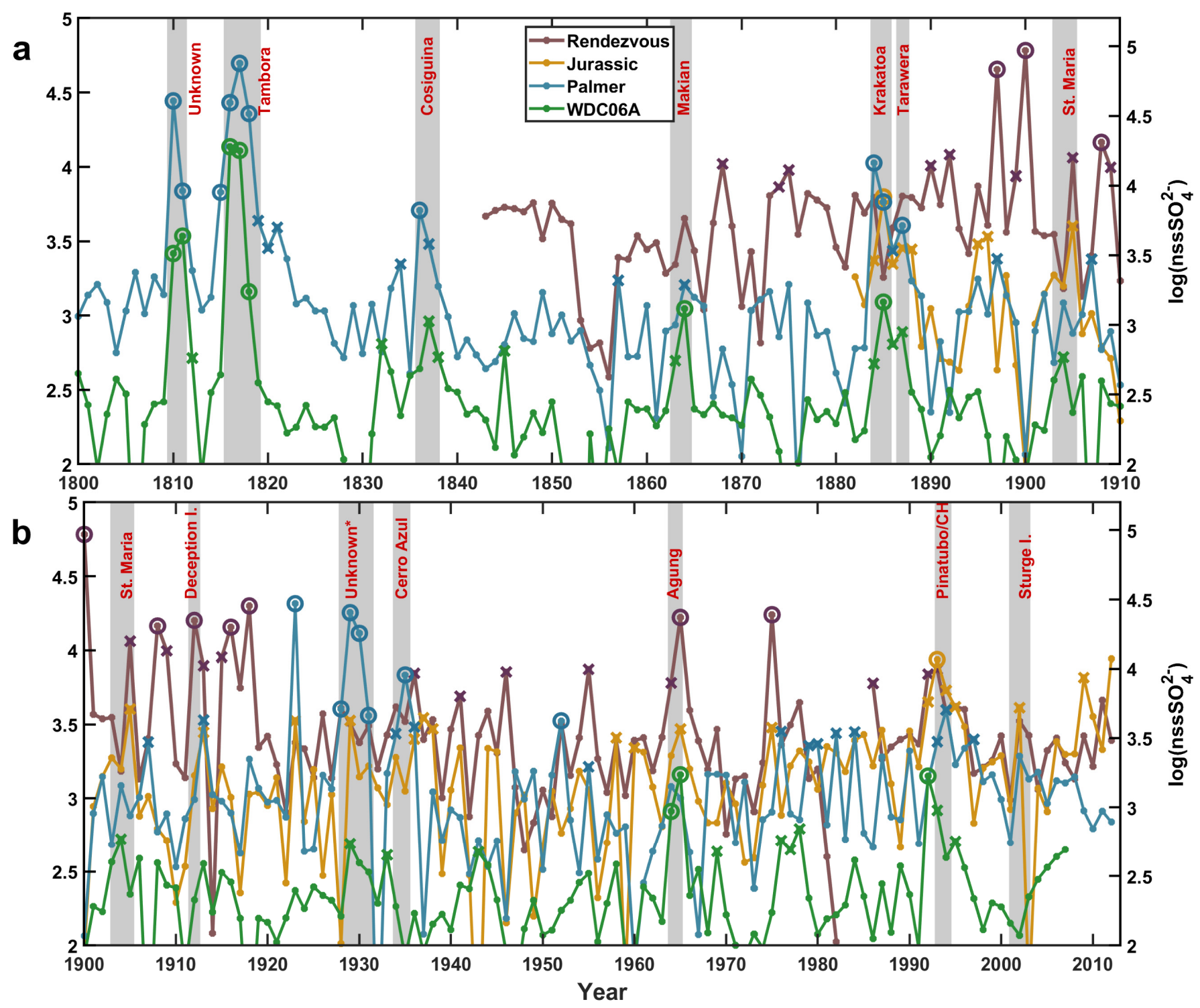

Figure 5. The log-normal of the annually averaged $\left[\mathrm{nsSO}_{4}{ }^{2-}\right]$ records for Palmer (blue line), Rendezvous (purple line), Jurassic (yellow line), and WDC06A (green line). (a) shows the 1800-1910 interval and (b) the 1900-2011 interval. Grey shading shows volcanic intervals with the corresponding event name in red. Unknown events identified in this study are marked as Unknown* Years when the $\left[\log \left(\left[\mathrm{nssSO}_{4}{ }^{2-}\right]\right) \geq\right.$ background $\left.+2 \sigma\right]$ are encircled and years when $\left[\right.$ background $+2 \sigma>\log \left(\left[\mathrm{nssSO}_{4}{ }^{2-}\right]\right) \geq$ background $\left.+1 \sigma\right]$ are indicated by exes.

All records show exceedances after the Cerro Azul 1932 eruption. This event was also reported in the Enderby Land core [33]. All records show a synchronous increase and are significant at the $1 \sigma$ level ( $2 \sigma$ for Palmer). This common increase amongst the records, constrains and adds confidence in the Rendezvous and Jurassic age scales, which are associated with few $2 \sigma$ exceedances.

Similar near-synchronous changes occur for Krakatoa and Tarawera (not apparent in Rendezvous), St. Maria, Agung [not significant for the Palmer $\log \left(\left[\mathrm{nssSO}_{4}{ }^{2-}\right]\right)$ test, but significant for the other significant tests (Table 2a)], Pinatubo/ $\mathrm{CH}$, and Sturge Island (Figure $5 b$ ). This demonstrates the advantage of dating several regional cores at the same time.

In particular, confidence in age scales for lower elevation sites can be gained by simultaneously evaluating and finding synchronic peaks with higher elevation sites (here, Palmer and WDC; associated with additional significant $2 \sigma$ exceedances). This approach 
makes it possible to decipher the volcanic signal from lower elevation sites for which the biogenic background signal is higher. However, note that none of the examined sites are coastal sites (Table 1). Moreover, the high-accumulation Rendezvous and Jurassic sites provide high-resolution records enabling unambiguous layer-counting.

The Jurassic record shows an exceedance ( $1 \sigma$ level) and the Palmer and Rendezvous $\left[\mathrm{nsSSO}_{4}{ }^{2-}\right.$ ] records an increase around 2002 (Figure 5b). Sulfate peaks have been identified around this time in other Antarctic cores and a new study suggests that this peak corresponds to a Sturge Island 2001 eruption [34].

The Rendezvous [nssSO ${ }_{4}{ }^{2-}$ ] record has a period, 1890-1918, of elevated [nssSO ${ }_{4}{ }^{2-}$ ] concentration values (Figure 5). This period of higher $\left[\mathrm{nsSO}_{4}{ }^{2-}\right.$ ] values can either be due to a local eruption, from a local decline in sea ice (closer proximity to a biogenic source), or from contamination. Some support for the first notion comes from the high-resolution $\left[\mathrm{nssSO}_{4}{ }^{2-}\right.$ ] record which shows local peaks outside of the summer season (not the season when you would expect [nssSO ${ }_{4}{ }^{2-}$ ] from a biogenic nor distant volcanic source to peak). However, it could also correspond to a period of increased biogenic background when the volcanic signal is harder to decipher. St. Maria is the only potential match with a volcanic horizon during this period. A similarly elevated $\left[\mathrm{nsSO}_{4}{ }^{2-}\right]$ concentration period is not present in the Jurassic core. Consequently, amongst these two lower-elevation sites the Jurassic core shows several matches with volcanic events for its deeper/older part (Krakatoa and Tarawera), and its age scale is, therefore, better constrained (Figure 5a).

\section{Summary}

In this study, we present the Palmer, Rendezvous, and Jurassic ice-core chronologies. The age scales are derived using annual-layer counting and the accuracy is evaluated against known volcanic horizons. The Palmer chronology covers 390 years, 1621-2011 C.E., and is one of the oldest AP records yet available that also has substantial overlap with observational records $[10,18-20]$. The Rendezvous and Jurassic ice cores cover the 1843-2011 and 1874-2011 C.E. periods, respectively. Non-sea-salt sulfate was used as the main chemical signal for picking annual layers, with $\delta^{18} \mathrm{O}, \mathrm{H}_{2} \mathrm{O}_{2}$, and MSA peaks providing additional support. The accuracy of the chronologies was evaluated against known volcanic event horizons. The Palmer chronology is compared to the WAIS Divide ice core chronology, the average difference between the cores' volcanic horizon start and end date is less than 6 months. The high accuracy of the age scales, and that the uncertainty does not increase with depth, indicate that interannual ice core proxy correlations can be performed with observational and model data throughout the extent of the cores. This study shows the advantage of dating several regional cores at the same time. Increased confidence in age scales can be gained, by simultaneously evaluating and finding synchronic changes amongst the sites.

Author Contributions: Conceptualization, B.D.E. and E.R.T.; methodology, B.D.E. and E.R.T.; software, B.D.E.; validation, B.D.E., E.R.T. and D.R.T.; formal analysis, B.D.E.; investigation, B.D.E.; resources, E.R.T.; data curation, B.D.E., E.R.T., D.R.T., J.D.H., and D.O.V.; writing-original draft preparation, B.D.E.; writing-review and editing, B.D.E., E.R.T., D.R.T., J.D.H., D.O.V.; visualization, B.D.E.; supervision, E.R.T.; project administration, E.R.T.; funding acquisition, E.R.T. All authors have read and agreed to the published version of the manuscript.

Funding: The ice core drilling and analysis was funded by the British Antarctic Survey, Natural Environment Research Council (NERC, Cambridge, UK), part of UK research and innovation and NERC grant [NE/J020710/1]. Palmer analysis was funded by Haus der Kulturen der Welt (HKW, Berlin, Germany), in collaboration with the Anthropocene working group (AWG).

Data Availability Statement: The age scale data will be available at the UK Polar Data Centre (https:/ / www.bas.ac.uk/data/uk-pdc/, accessed on 29 January 2022) after acceptance. The Palmer age-scale is part of the Global Boundary Stratotype Section and Point (GSSP) submission for the Anthropocene Working Group (AWG) and is embargoed until Summer 2022. 


\begin{abstract}
Acknowledgments: Analysis of the Palmer core was facilitated by the collaborative research project between BAS and the Anthropocene Working Group (AWG) to ratify the stratigraphic Anthropocene. The AWG is coordinating the assessment of candidate GSSP sites in collaboration with the Haus der Kulturen der Welt (HKW, Berlin) in the framework of its long-term project Anthropocene Curriculum. The Anthropocene Curriculum is an international project for experimental forms of Anthropocene research and education developed by HKW and the Max Planck Institute for the History of Science (MPIWG, Berlin) since 2013. We acknowledge Julius Rix and Catrin Thomas for drilling and field support and Shaun Miller and Emily Ludlow for laboratory support.
\end{abstract}

Conflicts of Interest: The authors have no conflict of interest to declare.

\title{
References
}

1. EPICA. Community Members Eight Glacial Cycles from an Antarctic Ice Core. Nature 2004, 429, 623-628. [CrossRef] [PubMed]

2. Sinclair, K.E.; Bertler, N.A.N.; Bowen, M.M.; Arrigo, K.R. Twentieth Century Sea-Ice Trends in the Ross Sea from a High-Resolution, Coastal Ice-Core Record. Geophys. Res. Lett. 2014, 41, 3510-3516. [CrossRef]

3. Thomas, E.R.; Abram, N.J. Ice Core Reconstruction of Sea Ice Change in the Amundsen-Ross Seas since 1702 A.D. Geophys. Res. Lett. 2016, 43, 5309-5317. [CrossRef]

4. Winstrup, M.; Vallelonga, P.; Kjær, H.A.; Fudge, T.J.; Lee, J.E.; Riis, M.H.; Edwards, R.; Bertler, N.A.N.; Blunier, T.; Brook, E.J.; et al. A 2700-Year Annual Timescale and Accumulation History for an Ice Core from Roosevelt Island, West Antarctica. Clim. Past Discuss. 2017, 2017, 1-46. [CrossRef]

5. $\quad$ Pruett, L.E.; Kreutz, K.J.; Wadleigh, M.; Mayewski, P.A.; Kurbatov, A. Sulfur Isotopic Measurements from a West Antarctic Ice Core: Implications for Sulfate Source and Transport. Ann. Glaciol. 2004, 39, 161-168. [CrossRef]

6. Steig, E.J.; Mayewski, P.A.; Dixon, D.A.; Kaspari, S.D.; Frey, M.M.; Schneider, D.P.; Arcone, S.A.; Hamilton, G.S.; Spikes, V.B.; Albert, M.; et al. High-Resolution Ice Cores from USITASE (West Antarctica): Development and Validation of Chronologies and Determination of Precision and Accuracy. Ann. Glaciol. 2005, 41, 77-84. [CrossRef]

7. Abram, N.J.; Wolff, E.W.; Curran, M.A.J. A Review of Sea Ice Proxy Information from Polar Ice Cores. Quat. Sci. Rev. 2013, 79, 168-183. [CrossRef]

8. Sigg, A.; Neftel, A. Seasonal Variations in Hydrogen Peroxide in Polar Ice Cores. Ann. Glaciol. 1988, 10, 157-162. [CrossRef]

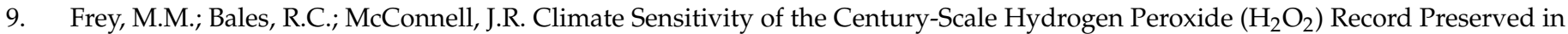
23 Ice Cores from West Antarctica. J. Geophys. Res. Atmos. 2006, 111, D21301. [CrossRef]

10. Thomas, E.R.; Marshall, G.J.; McConnell, J.R. A Doubling in Snow Accumulation in the Western Antarctic Peninsula since 1850. Geophys. Res. Lett. 2008, 35, L01706. [CrossRef]

11. Hoffmann, K.; Fernandoy, F.; Meyer, H.; Thomas, E.R.; Aliaga, M.; Tetzner, D.; Freitag, J.; Opel, T.; Arigony-Neto, J.; Göbel, C.F.; et al. Stable Water Isotopes and Accumulation Rates in the Union Glacier Region, Ellsworth Mountains, West Antarctica, over the Last 35 Years. Cryosphere 2020, 14, 881-904. [CrossRef]

12. Moser, D.E.; Jackson, S.; Kjær, H.A.; Markle, B.; Ngoumtsa, E.; Pedro, J.B.; Segato, D.; Spolaor, A.; Tetzner, D.; Vallelonga, P.; et al. An Age Scale for the First Shallow (Sub-)Antarctic Ice Core from Young Island, Northwest Ross Sea. Geosciences 2021, 11, 368. [CrossRef]

13. Sigl, M.; Fudge, T.J.; Winstrup, M.; Cole-Dai, J.; Ferris, D.; McConnell, J.R.; Taylor, K.C.; Welten, K.C.; Woodruff, T.E.; Adolphi, F.; et al. The WAIS Divide Deep Ice Core WD2014 Chronology_Part 2: Annual-Layer Counting (0-31 \,Ka \,BP). Clim. Past 2016, 12, 769-786. [CrossRef]

14. Cole-Dai, J.; Mosley-Thompson, E. The Pinatubo Eruption in South Pole Snow and Its Potential Value to Ice-Core Paleovolcanic Records. Ann. Glaciol. 1999, 29, 99-105. [CrossRef]

15. Castellano, E.; Becagli, S.; Jouzel, J.; Migliori, A.; Severi, M.; Steffensen, J.P.; Traversi, R.; Udisti, R. Volcanic Eruption Frequency over the Last $45 \mathrm{Ky}$ as Recorded in Epica-Dome C Ice Core (East Antarctica) and Its Relationship with Climatic Changes. Glob. Planet. Change 2004, 42, 195-205. [CrossRef]

16. Nardin, R.; Amore, A.; Becagli, S.; Caiazzo, L.; Frezzotti, M.; Severi, M.; Stenni, B.; Traversi, R. Volcanic Fluxes Over the Last Millennium as Recorded in the Gv7 Ice Core (Northern Victoria Land, Antarctica). Geosciences 2020, 10, 38. [CrossRef]

17. Cole-Dai, J.; Mosley-Thompson, E.; Thompson, L.G. Quantifying the Pinatubo Volcanic Signal in South Polar Snow. Geophys. Res. Lett. 1997, 24, 2679-2682. [CrossRef]

18. Thomas, E.R.; Bracegirdle, T.J. Precipitation Pathways for Five New Ice Core Sites in Ellsworth Land, West Antarctica. Clim. Dyn. 2015, 44, 2067-2078. [CrossRef]

19. Dee, D.P.; Uppala, S.M.; Simmons, A.J.; Berrisford, P.; Poli, P.; Kobayashi, S.; Andrae, U.; Balmaseda, M.A.; Balsamo, G.; Bauer, P.; et al. The ERA-Interim Reanalysis: Configuration and Performance of the Data Assimilation System. Q. J. R. Meteorol. Soc. 2011, 137, 553-597. [CrossRef]

20. Fretwell, P.; Pritchard, H.D.; Vaughan, D.G.; Bamber, J.L.; Barrand, N.E.; Bell, R.; Bianchi, C.; Bingham, R.G.; Blankenship, D.D.; Casassa, G.; et al. Bedmap2: Improved Ice Bed, Surface and Thickness Datasets for Antarctica. Cryosphere 2013, 7, $375-393$. [CrossRef] 
21. Greene, C.A.; Gwyther, D.E.; Blankenship, D.D. Antarctic Mapping Tools for Matlab. Comput. Geosci. 2017, 104, 151-157. [CrossRef]

22. Grieman, M.M.; Hoffmann, H.M.; Humby, J.D.; Mulvaney, R.; Nehrbass-Ahles, C.; Rix, J.; Thomas, E.R.; Tuckwell, R.; Wolff, E.W. Continuous Flow Analysis Methods for Sodium, Magnesium and Calcium Detection in the Skytrain Ice Core. J. Glaciol. 2021, 68, 90-100. [CrossRef]

23. Bigler, M.; Svensson, A.; Kettner, E.; Vallelonga, P.; Nielsen, M.E.; Steffensen, J.P. Optimization of High-Resolution Continuous Flow Analysis for Transient Climate Signals in Ice Cores. Environ. Sci. Technol. 2011, 45, 4483-4489. [CrossRef] [PubMed]

24. Gkinis, V.; Popp, T.J.; Johnsen, S.J.; Blunier, T. A Continuous Stream Flash Evaporator for the Calibration of an IR Cavity Ring-down Spectrometer for the Isotopic Analysis of Water. Isotopes Environ. Health Stud. 2010, 46, 463-475. [CrossRef] [PubMed]

25. Gkinis, V.; Popp, T.J.; Blunier, T.; Bigler, M.; Schüpbach, S.; Kettner, E.; Johnsen, S.J. Water Isotopic Ratios from a Continuously Melted Ice Core Sample. Atmos. Meas. Tech. 2011, 4, 2531-2542. [CrossRef]

26. Jones, T.R.; White, J.W.C.; Steig, E.J.; Vaughn, B.H.; Morris, V.; Gkinis, V.; Markle, B.R.; Schoenemann, S.W. Improved Methodologies for Continuous-Flow Analysis of Stable Water Isotopes in Ice Cores. Atmos. Meas. Tech. 2017, 10, 617-632. [CrossRef]

27. Emanuelsson, B.D.; Baisden, W.T.; Bertler, N.A.N.; Keller, E.D.; Gkinis, V. High-Resolution Continuous-Flow Analysis Setup for Water Isotopic Measurement from Ice Cores Using Laser Spectroscopy. Atmos. Meas. Tech. 2015, 8, 2869-2883. [CrossRef]

28. Maselli, O.J.; Fritzsche, D.; Layman, L.; McConnell, J.R.; Meyer, H. Comparison of Water Isotope-Ratio Determinations Using Two Cavity Ring-down Instruments and Classical Mass Spectrometry in Continuous Ice-Core Analysis. Isot. Environ. Health Stud. 2013, 49, 387-398. [CrossRef]

29. Mulvaney, R.; Pasteur, E.C.; Peel, D.A.; Saltzman, E.S.; Whung, P.-Y. The Ratio of MSA to Non-Sea-Salt Sulphate in Antarctic Peninsula Ice Cores. Tellus B 1992, 44, 295-303. [CrossRef]

30. Emanuelsson, B.D.; Humby, J.D.; Tetzner, D.R.; Thomas, E.R.; Vladimirova, D.O. Ages Scales for the Palmer, Jurassic, and Rendezvous Antarctic Peninsula Ice Cores (Version 1.0) [Data Set]. NERC EDS UK Polar Data Cent. 2022. [CrossRef]

31. Küttel, M.; Steig, E.J.; Ding, Q.; Monaghan, A.J.; Battisti, D.S. Seasonal Climate Information Preserved in West Antarctic Ice Core Water Isotopes: Relationships to Temperature, Large-Scale Circulation, and Sea Ice. Clim. Dyn. 2012, 39, 1841-1857. [CrossRef]

32. Sigl, M.; McConnell, J.R.; Layman, L.; Maselli, O.; McGwire, K.; Pasteris, D.; Dahl-Jensen, D.; Steffensen, J.P.; Vinther, B.; Edwards, R.; et al. A New Bipolar Ice Core Record of Volcanism from WAIS Divide and NEEM and Implications for Climate Forcing of the Last 2000 Years. J. Geophys. Res. Atmos. 2013, 118, 1151-1169. [CrossRef]

33. Kohno, M.; Fujii, Y. Past 220 Year Bipolar Volcanic Signals: Remarks on Common Features of Their Source Volcanic Eruptions. Ann. Glaciol. 2002, 35, 217-223. [CrossRef]

34. Tetzner, D.R.; Thomas, E.R.; Allen, C.S.; Piermattei, A. Evidence of Recent Active Volcanism in the Balleny Islands (Antarctica) From Ice Core Records. J. Geophys. Res. Atmos. 2021, 126. [CrossRef] 